\title{
Plough pan impacts maize grain yield, carbon assimilation, and nitrogen uptake in the corn belt of Northeast China
}

\author{
Qingjun Cao"*, Gang Li*, Fentuan Yang1, Xiaoli Jiang, Lamine Diallo², Xifeng Chen' \\ ${ }^{1}$ Jilin Academy of Agriculture Science, Key Laboratory of Northeast Crop Physiology Ecology and Cultivation, Ministry of Agriculture in \\ People's Republic of China, Changchun 130033, P.R. China, ${ }^{2}$ College of Plant Science, Jilin University, Changchun 130062, P.R China
}

\section{A B S T R A C T}

\begin{abstract}
This study aims to investigate the responses of carbon assimilation, grain yield, leaf stay-green rate, nitrogen uptake and distribution to soil compaction in the hard plow pan caused by repeated use of tractor-driven cultivator in Northeast China. The typical hybrid maize variety "Zhengdan 958" was exposed to two treatments of simulated plow pan (SP) and simulated subsoiling (SS, control) in pot experiments from 2012 to 2014. Compared with SS, SP significantly reduced net photosynthetic rate (Pn) during growth stage, leading to a decrease in dry matter accumulation (DMA) and grain yield (GY) in three consecutive experimental years. Leaf stay-green degrees (LSD), which showed a fast descending trend from 20 days after silking (DAS), significantly decreased in the later filling stage under SP treatment. The translocation effciency of the stored N (TEN) in stalk and leaf to the grain during pre-silking was enhanced, whereas leaf and grain $\mathrm{N}$ concentration (LNC/GNC), together with $\mathrm{N}$ accumulation amounts at maturity were significantly reduced under SP treatment. Also, plough pan reduced the $\mathrm{N}$ distribution to the organs of stalk, leaf and grain. In conclusion, subsoiling is a possible way to delay leaf senescence and achieve higher DMA and GY, and increased grain $\mathrm{N}$ in the corn belt of Northeast China.
\end{abstract}

Keywords: Plough pan; Subsoiling; Leaf stay-green; N uptake; $\mathrm{N}$ concentration

\section{INTRODUCTION}

Maize (Zea mays L.) is one of the world's three major cereals crops, which is considered as a major source of staple food. The grain protein concentration is closely related to the nitrogen $(\mathrm{N})$ content ( $\mathrm{Li}$ et al., 2016), and dry mass in maize grains is an important nutrition factor, which is associated with human health and animal feeding (Masclaux et al., 2008).

The genetic gain in total grain yield can be attributed predominantly to the increased dry matter accumulation (Tollenaar, 1989). It has been well-known that maize grain accumulation could be explained by post-silking dry matter accumulation and/or remobilization of dry matter stored in the stem and leaf during vegetative growth (Ning et al., 2013). Hence, enhancement of post-silking dry matter accumulation and remobilization of dry matter stored in the early growth stage is important approachs to increase maize grain yield in modern agricultural manage practice. Many precious researches have demonstrated that leaf stay-green ability has a significant positive correlation with maize grain yield (Martin et al., 2005). The increment in ear fertility and grain-filling rate, and delayed leaf senescence with unchanged net photosynthetic rate are the significant characteristics for a modern breeding maize hybrids (Chen et al., 2013).

However, senescence is the point in the plant life cycle, which is one of the major determinants of crop performance converge (Robson et al., 2004). The conspicuous visual symptoms of leaf senescence are the loss of chlorophyll pigments, desiccation, and eventual abscission (He and Wasaki, 2005). The initiation and progression of leaf senescence can be modulated by internal factors (such as plant hormones and plant growth regulators) and various environmental factors, such as temperature or drought status, mineral supplying capacity (Masclaux et al., 2008b;

\footnotetext{
*Corresponding author:

Qingjun Cao, Jilin Academy of Agriculture Science, Key Laboratory of Northeast Crop Physiology Ecology and Cultivation, Ministry of Agriculture in People's Republic of China, Changchun 130033, P.R. China. E-mail: qjcao8899@cjaas.com, laoli201@yeah.net
} 
Kosgey et al., 2013), soil water conditions (Széles et al., 2012; Thoiron and Briat, 1999), and soil compactions (Li et al., 2013).

Subsoil compaction is caused by ever increasing wheel loads in agricultural machinery for agricultural land, which is becoming a global problem. It presented increasing risk in both developed and developing countries (Cai et al., 2014; Bertolino et al., 2010). In Northeast China, plough pan formation is considered to be a consequence of conventional tillage practices. The repeated use of tractordriven cultivator and long-term monocultures of spring maize resulted in a hard pan in the depth of ca. $15 \mathrm{~cm}$ in soil (Cai et al., 2014b), which has negative effects on soil physical and chemical properties, including pore size, porosity, and infiltration that hinder the movement of air and water into soil (Jiang et al., 2015). Consequently, the restricted maize growth may reduce the maintenance of photosynthetic capability or $\mathrm{N}$ supply during the grain filling period (Borrell and Hammer, 2000). These may in turn influence the $\mathrm{N}$ balance and lead to the reduction of leaf stay-green degree during maize growth stage, due to limited water and nutrient availability (Bertolino et al., 2010b).

Carbon and nitrogen $(\mathrm{N})$ metabolisms are fundamental processes in plants. It is well known that assimilation of $\mathrm{N}$ requires energy and $\mathrm{C}$ skeletons produced by $\mathrm{C}$ metabolism, and assimilation of photosynthetic $\mathrm{C}$ requires a large amount of $\mathrm{N}$ (Nunes-Nesi, et al. 2010). Ishaq, et al. (2001) demonstrated that an increase in bulk density (from 1.65 to1.93 $\mathrm{Mg} \mathrm{m}^{-3}$ ) due to subsoil compaction decreased the nutrient uptake in wheat and sorghum plants. Whereas lots of studies found that in stay-green maize hybrids the higher retention of leaf $\mathrm{N}$ may lead to a decline in kernel $\mathrm{N}$ content (Acciaresi et al., 2014; Chen et al., 2014). However, it is rarely known whether leaf stay-greenness caused by soil compaction influenced $\mathrm{N}$ accumulation, remobilization and distribution in maize plants under repeated use of small tractors in developing countries. Thus, the purpose of this study is to examine: (1) the effect of plough pan on photosynthetic capability, carbon assimilation and leaf staygreen rate during post-anthesis; (2) the effect of plough pan on $\mathrm{N}$ accumulation, remobilization and distribution in Jilin province, Northeast China.

\section{MATERIALS AND METHODS}

\section{Experimental setup}

The study was carried out at the experimental field of Jilin Academy of Agricultural Sciences, Changchun, Jilin province (434' 7 "N, $\left.125^{\circ} 23^{\prime} 47^{\prime \prime E}\right)$ during 2012-2014. The site is located in north temperate continental monsoon climate zone, and the annual precipitation is about 500 to $900 \mathrm{~mm}$ with $70 \%$ of the total rainfall received during the summer (July-August). The average air temperature was $19.45^{\circ} \mathrm{C}$ and the number of frost-free day ranged between 125 to140 days during the maize growth season. The total precipitation during the maize growing seasons in the years 2012-2013 were 546.5 and $627.6 \mathrm{~mm}$, respectively.

The typical hybrid maize variety "Zhengdan 958" was used in the experiments, which is the elite variety widely used in this region. The soil was a loam, with a $\mathrm{pH}$ of 6.5 . Other chemical properties of the soil were shown in Table 1.

Two corn seeds with similar size were sown in a PVC pipe (25 $\mathrm{cm}$ in diameter, $75 \mathrm{~cm}$ in length), and thinned to one at 4-leaf stage. The pipes were buried underground in the field by keeping $5 \mathrm{~cm}$ above the ground. For the simulated plow pan (SP) treatment, the plow pan was $15 \mathrm{~cm}$ beneath the top soil, it was about $15 \mathrm{~cm}$ thick with a bulk density of $1.85 \mathrm{~g} \mathrm{~cm}^{-3}$, while the soil weight was $1.2 \mathrm{~g} \mathrm{~cm}^{-3}$ for the simulated sub-soiling (SS) treatment. During the whole growing period, the maize plants were grown under rainfed condition, except for only once irrigation with equal amount of water at seeding.

\section{Treatments and feeding criteria}

Each of the treatments includes 24 tubes. Seeds were planted on $5^{\text {th }}$ and $7^{\text {th }}$ of May in 2012 and 2013, respectively. The row spacing between lines of tubes was $60 \mathrm{~cm}$ and the distance between tubes within the rows was $33 \mathrm{~cm}$. Field management and fertilization were carried out according to farmers' practices [basal fertilizer was applied $500 \mathrm{~kg}$ ha ${ }^{-1}$ compound Fertilizer $\left(\mathrm{N}: \mathrm{P}_{2} \mathrm{O}_{5}: \mathrm{K}_{2} \mathrm{O}=15: 15: 15\right)$, seed fertilizer $50 \mathrm{~kg} \mathrm{ha}^{-1}$ ammonium dihydrogen phosphate, top dressing $200 \mathrm{~kg} \mathrm{ha}^{-1} \mathrm{CO}\left(\mathrm{NH}_{2}\right)_{2}$ at the big trumpet period.

\section{Sampling and chemical analyses of plant tissue for $\mathbf{N}$ Concentration}

At V6 (6 leaf-stage), V8 and 0, 10, 20, 30, 40, 50 days after silking (DAS), samples of three successive plants were chosen, and the biomass were measured after oven-drying at $75{ }^{\circ} \mathrm{C}$ for 48 hrs. For silk and physiological maturity stages, selected plants were separated into leaf cob, stalk, and grain. The weight of each component was dried up (at $75^{\circ} \mathrm{C}$ ) to constant weight and weighed, dry grain yield and aboveground biomass were recorded. Then, the concentration of $\mathrm{N}$ was analyzed by Kjeldahl digestion method, and the remobilization of stored $\mathrm{N}$ from a given organ to grain (RAN) was calculated by subtracting the $\mathrm{N}$ at maturity from the $\mathrm{N}$ at silking in this organ (Chen et al., 2014 b; Li et al., 2016 b). The translocation effciency of the stored $\mathrm{N}$ in a given organ (TEN) was calculated following (1): 
Cao, et al:: Plow pan reduced carbon assimilation and $\mathrm{N}$ uptake

Table 1: Soil chemical properties of tube experiment site in Jilin province, northeast of China

\begin{tabular}{|c|c|c|c|c|}
\hline Year & Organic matter $\mathbf{g ~ k g}^{-1}$ & Alkali-hydrolyzed $\mathrm{N} \mathrm{g} \mathrm{kg}^{-1}$ & Olsen-P g kg ${ }^{-1}$ & NH4OAc-extracted $\mathrm{K} \mathrm{g} \mathrm{kg}^{-1}$ \\
\hline 2012 & 16.43 & 127.2 & 19.5 & 101.0 \\
\hline
\end{tabular}

TEN $(\%)=\mathrm{RAN} / \mathrm{N}$ amount at anthesis $\times 100$

The contribution of RAN to grain $\mathrm{N}$ (CRAN) was calculated following Equation (2):

CRAN $(\%)=\mathrm{RAN} / \mathrm{N}$ amount in grain at maturity $\times 100$

Leaf net Photosynthetic rate $\left(P_{n}\right)$ was measured with a Li6400 portable photosynthesis system (Li-cor Inc., USA) at V12, VT and R3 stage. Three plants of each treatment were selected for measuring. Measurements were taken on a $2.5 \mathrm{~cm}^{2}$ area in the center part of the leaf blade that did not include the midrib. Leaves of five plants in each treatment were counted with a ten-day interval after silking, and maximum length and width of each green leaf were measured in each plant. The green area of individual plant (3) and leaf stay-green degree (LSD) was calculated according to the given formulas:

Green leaf area $(G L A)=\sum$ Leaf length $\times$ leaf width $\times$ $0.75\left(\mathrm{~cm}^{2}\right)$

Stay-green degree $(\%)=$ Post-silking GLA/GLA at silking stage.

\section{Statistical analysis}

All statistical analysis of the data was applied by using SPSS 17.0 (IBM SPSS Inc., USA) after verifying the homogeneity of the error variances. Multiple comparisons among the treatments were analyzed with least significant difference (LSD) test at the 0.05 and 0.01 level of probability.

\section{RESULTS}

\section{Simulated plough pan and subsoiling impacts pn, and} leaf stay-green rate

Photosynthesis is a basic physiological process and the main factor that affects maize growth can be evaluated directly through measurement of photosynthetic parameters. Consistent result was observed in two years' experiments, Pn was significantly $(P<0.05)$ and highly significantly $(P<0.01)$ affected by determination stage and treatment (plough pan and subsoiling), respectively. Compared with SS plants, Pn was significantly reduced by $13.66 \%, 13.02 \%$ and $25.51 \%$ in in V12, VT and R3 stage in 2012 (Fig. 1a); whereas, it was reduced by $5.48 \%, 12.13 \%$ and $17.98 \%$ in 2013 (Fig. 1b), respectively.

Meanwhile, leaf senescence at post-silkng stage was monitored at a regular interval. LSD declined consistently during grain filling stage in two years (Fig. 2a and b), it exhibited a quicker descending trend from 20DAS, and the LSD was significantly reduced by SP at the same time. Taken for example measurements of the $50^{\text {th }}$ DAS, LSD under SS were 1.48 and 1.94 times larger than SP, indicating that leaf senescence might be accelerated due to existence of plough pan.

Simulated plough pan and subsoiling impacts dry matter accumulation (DMA), and grain yield (GY)

To determine if the reduction of Pn caused by plough pan decreased maize dry mass accumulation, we measured total dry mass accumulation (TDM), DMA pre-silking and postsilking together with individual GY (Table 2). Pre-silking DMA was significantly $(P<0.01)$ affected by treatment $(T)$, environment condition $(\mathrm{Y})$ and their interaction $(\mathrm{T} \times \mathrm{Y})$ (Table 2). Post-silking DMA, TDM and GY were also significantly $(P<0.01)$ reduced by hard pan. Pre-silking DMA, post-DMA, TDM and GY was reduced by $22.07 \%$, $5.70 \%, 14.15 \%$, and $8.59 \%$ on averaged values from three years, respectively.

Simulated plough pan and subsoiling impacts $\mathbf{N}$ concentration during silking and maturity stage

To determine if the loss of LSD impacted $\mathrm{N}$ concentration on stalk and leaf, we measured leaf $\mathrm{N}$ concentration (LNC) and stalk $\mathrm{N}$ concentration (SNC) in silking stage and mature stage together with grain $\mathrm{N}$ concentration (GNC) (Table 3). LNC and GNC in mature and LNC in silking stage were significantly influenced by plough pan, while no significant difference of SNC was found in both years. Compared to silking stage, LNC and SNC were highly decreased at mature due to remobilization of $\mathrm{N}$ in present study.

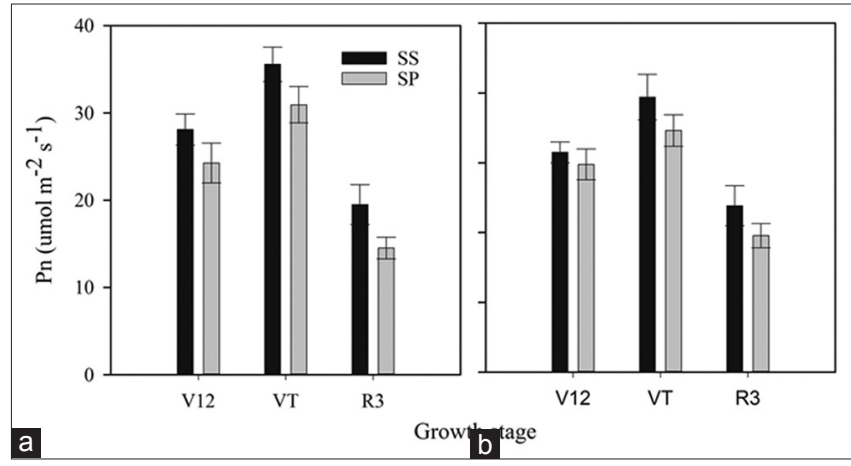

Fig 1. Simulated plough pan and subsoiling impacts Pn during V12, VT and R3 in 2012(a) and 2013(b). SS=simulated subsoiling; $\mathrm{SP}=$ simulated plough pan. 
Table 2: Stimulated plough pan and subsoiling Impacts maize dry matter accumulation and grain weight in consecutive year of 2012 to 2014

\begin{tabular}{|c|c|c|c|c|c|}
\hline \multirow[t]{2}{*}{ Year } & \multirow[t]{2}{*}{ Treatment } & \multicolumn{3}{|c|}{ Dry matter accumulation amount ( g plant $\left.^{-1}\right)$} & \multirow[t]{2}{*}{ Grain yield $\left(\right.$ g plant $\left.^{-1}\right)$} \\
\hline & & Pre-silking & Post-silking & Total & \\
\hline \multirow[t]{2}{*}{2012} & SS & $209.73 \pm 11.2 \dagger^{a}$ & $193.19 \pm 14.0^{\mathrm{a}}$ & $402.92 \pm 2.01^{\mathrm{a}}$ & $224.57 \pm 13.82^{\mathrm{a}}$ \\
\hline & SP & $151.04 \pm 10.4^{b}$ & $184.72 \pm 10.0^{\mathrm{b}}$ & $335.76 \pm 1.18^{b}$ & $167.11 \pm 22.74^{b}$ \\
\hline \multirow[t]{2}{*}{2013} & SS & $218.20 \pm 8.6^{a}$ & $198.16 \pm 9.18^{a}$ & $416.36 \pm 0.79^{a}$ & $234.70 \pm 18.29^{\mathrm{a}}$ \\
\hline & SP & $168.68 \pm 4.6^{b}$ & $177.37 \pm 10.1^{\mathrm{b}}$ & $346.05 \pm 1.02^{\mathrm{b}}$ & $172.70 \pm 17.56^{\mathrm{b}}$ \\
\hline \multirow[t]{2}{*}{2014} & SS & $210.81 \pm 7.70^{\mathrm{a}}$ & $207.13 \pm 12.3^{a}$ & $417.94 \pm 8.47^{\mathrm{a}}$ & $202.56 \pm 9.84^{a}$ \\
\hline & SP & $178.02 \pm 11.0^{b}$ & $202.27 \pm 12.0^{a}$ & $380.29 \pm 19.38^{b}$ & $184.07 \pm 11.27^{b}$ \\
\hline \multicolumn{6}{|c|}{ Source of variation } \\
\hline Treatment & & ** & ** & $\star *$ & ** \\
\hline Year & & $* *$ & * & * & * \\
\hline$T \times Y$ & & ** & * & * & * \\
\hline
\end{tabular}

†Value is mean of three replication, mean $\pm S D$; *and ${ }^{* *}$ means significant at 0.05 and 0.01 level, respectively; ns: not significant ( $\left.p>0.05\right)$ by Duncan's test

Table 3: Simulated plough pan and subsoiling impacts $\mathbf{N}$ concentration at silking and maturity stage in 2012 and 2013

\begin{tabular}{|c|c|c|c|c|c|c|}
\hline \multirow[t]{2}{*}{ Year } & \multirow[t]{2}{*}{ Treatment } & \multicolumn{2}{|c|}{$\begin{array}{c}\mathrm{N} \\
\text { concentration } \\
\text { at silking }(\%)\end{array}$} & \multicolumn{3}{|c|}{$\begin{array}{c}\mathrm{N} \text { concentration at } \\
\text { maturity }(\%)\end{array}$} \\
\hline & & stalk & leaf & stalk & leaf & Grain \\
\hline \multirow[t]{2}{*}{2012} & SS & $1.34 \dagger$ & 2.65 & 0.73 & 1.40 & 1.66 \\
\hline & SP & 1.31 & 2.48 & 0.69 & 1.21 & 1.55 \\
\hline \multirow[t]{2}{*}{2013} & SS & 1.40 & 2.54 & 0.71 & 1.42 & 1.61 \\
\hline & SP & 1.35 & 2.41 & 0.67 & 1.21 & 1.52 \\
\hline
\end{tabular}

Source of

variation

$\begin{array}{llllll}\text { Treatment } & \text { ns } & * & \text { ns } & * * & * \\ \text { Year } & \text { ns } & \text { ns } & \text { ns } & \text { ns } & \text { ns } \\ \text { T } \times \text { Y } & \text { ns } & \text { ns } & \text { ns } & \text { ns } & \text { ns }\end{array}$

$\mathrm{SS}=$ simulated subsoiling, $\mathrm{SP}=$ simulated plough pan, $\mathrm{T}=$ treatment, $\mathrm{Y}=$ year $\dagger$ Value is mean of three replication, mean $\pm \mathrm{SD}$; *and ${ }^{* *}$ means significant at 0.05 and 0.01 level, respectively; ns: not significant $(p>0.05)$ by Duncan's test

Simulated plough pan and subsoiling impacts $\mathbf{N}$ accumulation amounts and $\mathrm{N}$ distribution of maize main organs

$\mathrm{N}$ accumulation amounts differences can be explained by post-silking $\mathrm{N}$ accumulation and/or remobilization of $\mathrm{N}$ from vegetative organs. The total accumulation of $\mathrm{N}$ during vegetative stage (Pre-silking) and reproductive stage (Post-silking), together with $\mathrm{N}$ distribution to organs of stalk, leaf and grain at maturity were significantly different in consecutive two years. Compared with SS maize plants, $\mathrm{N}$ accumulation amounts were reduced by $14.63 \%$ and $24.92 \%$ on average during vegetative growth stage and post-silking stage, respectively (Fig. 3). It was also showed a similar changed trend for $\mathrm{N}$ distribution amount among different organs of plants. The amount of $\mathrm{N}$ distribution to the organs of stalk, leaf and grain was reduced by $22.39 \%$, $33.31 \%$ and $21.12 \%$ on two years average (Fig. 4).

Simulated plough pan and subsoiling impacts remobilization of the stored $\mathbf{N}$ before silking to the grain To the opposite of $\mathrm{N}$ accumulation, the translocation efficiency of the stored $\mathrm{N}$ (TEN) during pre-silking in

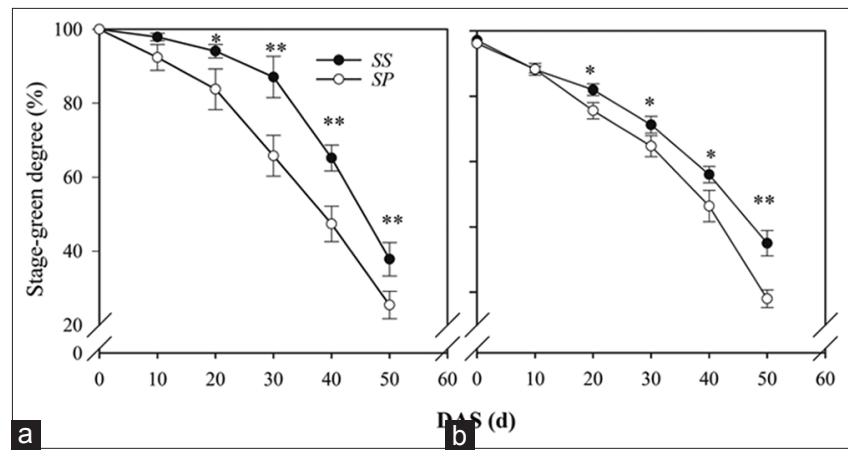

Fig 2. Effect of plough pan on maize leaf stay-green rate at post- silking in 2012(a) and 2013(b). SS=simulated subsoiling; SP= simulated plough pan; *and ${ }^{* \star}$ means significant at 0.05 and 0.01 level, respectively.

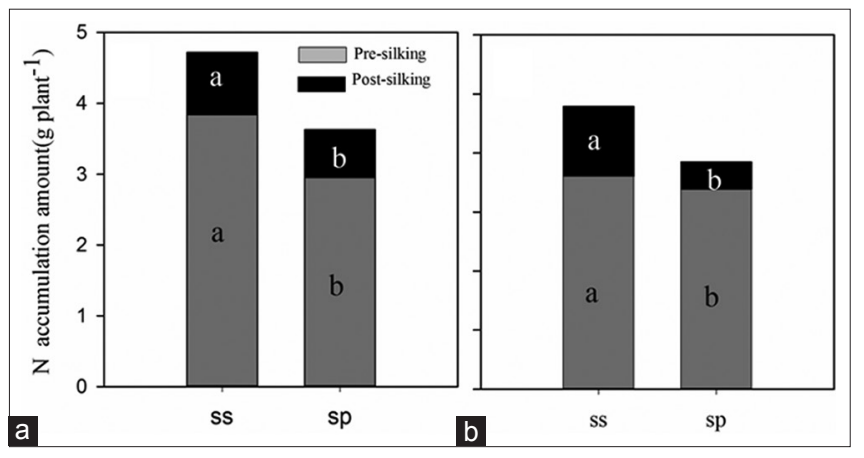

Fig 3. Simulated plough pan and subsoiling impacts $\mathrm{N}$ accumulation from emergence to silking (Pre-silking), and from silking to maturity (Post-silking) stage in 2012 (a) and 2013 (b). SS=simulated subsoiling; $\mathrm{SP}=$ simulated plough pan.

the stalk and leaf to the grain was significantly higher than the value of TEN under SS treatment (Fig. $5 \mathrm{a}$ and $5 \mathrm{~b}$ ). Compared to the treatment of SS, the contribution ratio to grain (CRG) of $\mathrm{N}$ in leaf and stalk by SP during growth period was also higher, especially for $\mathrm{CRG}$ of $\mathrm{N}$ in stem.

\section{DISCUSSION}

In recent years, the prolonged use of small-sized fourwheeled tractors on farm operation in developing countries 


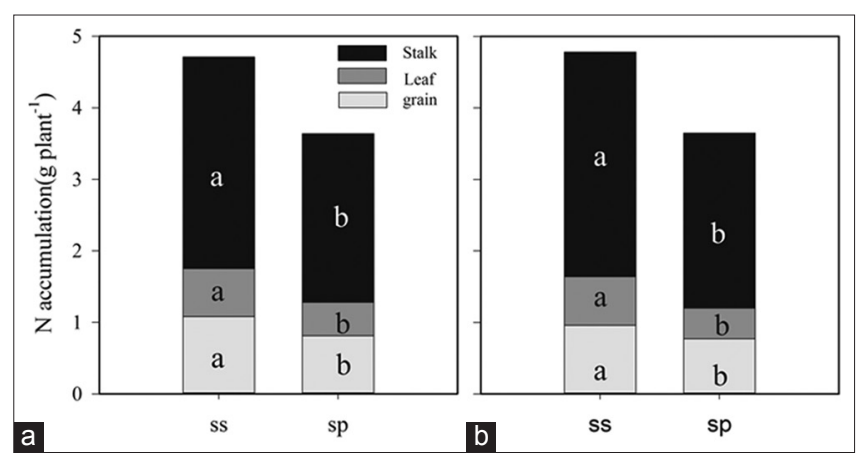

Fig 4. Simulated plough pan and subsoiling impacts $\mathrm{N}$ distribution to organs of stalk, leaf and grain at maturity stage in 2012(a) and 2013(b). $\mathrm{SS}=$ simulated subsoiling; $\mathrm{SP}=$ simulated plough pan.

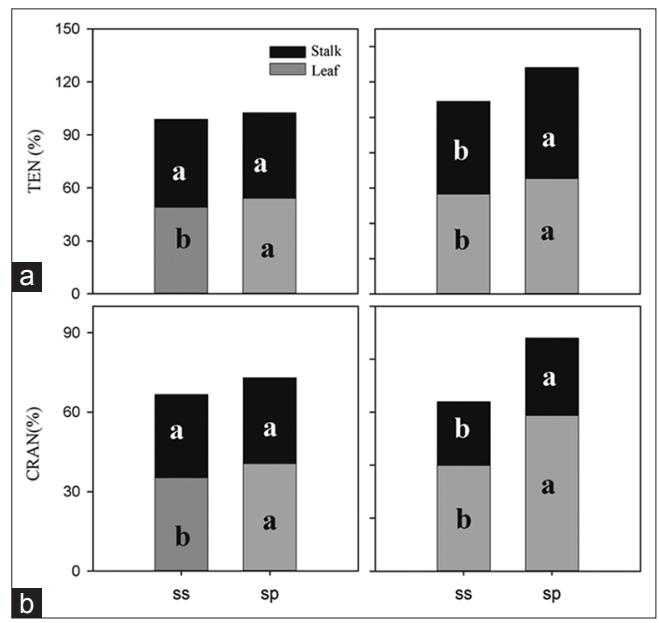

Fig 5. Translocation efficiency of the stored $\mathrm{N}$ in Stalk and leaf from emergence to silking into grains (TEN) in 2012(a) and 2013(b), and contribution of $\mathrm{N}$ absorbed during periods from emergence to silking into grains (CRAN) in 2012(c) and 2013(d). SS=simulated subsoiling; $\mathrm{SP}=$ simulated plough pan. Different small letters for the same organ (stalk and leaf) indicate significant difference at 0.05 levels between two treatments.

(Reicosky and Archer, 2007), has deteriorated the physical conditions of the soils and caused soil compaction. Subsoil compaction, which has been shown to affect both dry matter accumulation amount and leaf senescence during post-silking stage (Hassan et al., 2007; Li et al., 2013b), has been a global problem and an increasing risk in many of developed and developing countries. Moderate soil compaction benefits root nutrient uptake, soil water balance and crop yield. In the present study, it was observed that both DMA (pre-silking and post-silking) and GY were significantly decreased by SP, indicating that the plough pan depressed the maize growth and development in both vegetative and reproductive stages.

Photosynthesis is a basic physiological process for plant growth and dry biomass accumulation and the main factor affecting maize grain formation during grain filling stage (Xu et al.,2016). Pn of ear leaf in maize could partly indicate the photosynthetic capacity, thus it is the key factor to determine grain yield (Kim et al., 2006). The value of Pn were significantly reduced by plough pan in this study. Kosgey. et al. (2013b) demonstrated that there is a close correlation between season long canopy photosynthesis rate and biomass and grain yield, respectively. As we all known, grain filing stage is the key period for kernel growth. A significant reduction in $\mathrm{Pn}$ at $\mathrm{R} 3$ stage was found in two years, which most likely accounts for the grain yield reduction under plough pan.

Senescence is not only regulated by autonomous, but also by environmental signals. Leaf senescence can reflect the post-silking leaf stay green ability for genotypic variation characteristics, hence affecting the maize production. It has been reported that the leaf stay-green type in maize hybrids could retain more photosynthetically active leaves to conduct carbon assimilation in the later plant growth stage (Borrell and Hammer, 2000b). In the present study, it was found that leaf stay-green degree declined consistently during grain filling stage, showing a quicker descending trend from 20 DAS. Also, it was significantly lower than simulated subsoiling in both years, indicating that leaf senescence might be accelerated, due to the existence of plough pan. Yield increases in stay-green types have been attributed directly to the maintenance of photosynthetic capability during the grain filling period (Borrell and Hammer, 2000c). Thus, the decrease of leaf stay-green degree might contribute to the reduction of $\mathrm{Pn}$ and dry mass accumulation during post-silking stage, which was consistent with previous reports (Moreno et al., 2003; Liu et al., 2015).

$\mathrm{N}$ is one of the major limiting macronutrients and plays an important role in plant growth and yield improvement, because of its fundamental roles in protein formation $(\mathrm{Li}$ et al., 2012). Leaf $\mathrm{N}$ status at anthesis, in particular LNC, was an important determinant of both the onset and rate of crop leaf senescence during grain filling (Paponov, 2003b). It was found that the shortfall in $\mathrm{N}$ supply for grain filling was greater in the senescent plants than staygreen plants, resulting in more accelerated leaf senescence in senescent plants. Stay-green plants at anthesis usually contained more $\mathrm{N}$ in leaves than those non-stay-green plants. In this study, LNC and GNC in mature and LNC in silking stage were significant higher than that under plough pan, while no significant differences in SNC was found. This is consistent with the previous study of Borrell and Hammer (2000d), where the difference in leaf $\mathrm{N}$ status at anthesis was found between stay-green and senescent sorghum hybrids. Previous studies have demonstrated the unbalance between $\mathrm{N}$ demand by the grain and $\mathrm{N}$ supply during grain filling was the main reason of leaf senescence (Borrell et al, 2001). Hence, N supply cannot meet the $\mathrm{N}$ demand by the grain, which might be the main reason of 
the decline of leaf stay-green rate under the treatment of stimulated plough pan.

The $\mathrm{N}$ utilization of plants includes several processes, such as uptake, assimilation, translocation, and remobilization. There are two sources of $\mathrm{N}$ for grain growth: concurrently absorbed $\mathrm{N}$ from the soil during post-silking and remobilization from pre-silking accumulated $\mathrm{N}$ of vegetative tissues (Ta and Weiland, 1992; Chen et al., 2014c). In the present study, $\mathrm{N}$ accumulation amounts during post-silking stage and pre-silking $\mathrm{N}$ uptake by SP treatment were both significantly decreased. Borrell (2001b) reported that at the leaf level, the longevity of photosynthetic apparatus is intimately related to nitrogen (N) status. Therefore, the decrease of pre-silking $\mathrm{N}$ uptake is closely related to Pn and DMA. Also, the N accumulation amounts during post-silking stage highly related to the dynamic changes of leaf stay-green ability during grain filling stage. This agrees with Paponov (1991), showing that nitrogen uptake is related to the demand for $\mathrm{N}$ within the plant and the availability of soluble carbohydrates in root. However, this needs to be further studied.

In this study, the total CRAN of stem and leaf ranged from $63.99 \%$ to $68.69 \%$ and from $71.04 \%$ to $88.0 \%$ under SS and SP treatment, respectively. In a line with these findings, the pre-silking $\mathrm{N}$ remobilization contributed to the grain $\mathrm{N}$ by $66-85 \%$ by in the field in central region of Jilin province, Northeast China (Chen et al. 2014d). However, the stem contributions little more to grain N, in relation to the leaf. This is consistent with the result of $\mathrm{Li}$ et al., where the leaf and stem have nearly equal contributions to the grain $\mathrm{N}$ in winter wheat in Europe (2016c). Besides, the CRAN under SP was significantly higher than that under SS, mainly due to the differences in TEN between SP and SS treatment. The TEN of stem was slightly higher than that of leaf, indicating that the accumulation of $\mathrm{N}$ in grain after anthesis was mainly attributed to the remobilization of $\mathrm{N}$ assimilated in stem during the vegetative growth phase.

\section{CONCLUSION}

Net photosynthetic rate (Pn) was reduced by SP treatment during growth season, leading to a decrease in DMA and GY in three years. The LSD was also significantly reduced in the later filling stage. The TEN of stalk and leaf to the grain during pre-silking was enhanced, whereas the LNC, GNC, and N accumulation amounts were significantly reduced. Therefore, subsoiling is a possible way to delay leaf senescence and achieve higher DMA, GY and grain N.

\section{ACKNOWLEGMENTS}

We express our sincere thanks to the National Key Technology Research and Development Program of the Ministry of Science and Technology of China (No.2013BAD07B02) and the foundation of Program of Technology R\&D Foundation of Jilin Provence (No.2015GJLS003NY) for financially support. We are also thankful to Dr. Fulai Liu and Xiangnan Li (University of Cope-nhagen) for helping us in editing the manuscript.

\section{Author's contributions}

All authors contributed extensively to the work presented in this manuscript. Q. C. wrote the article and corrected it. G. L. designed and performed research and revised the manuscript. F.Y., X.C., Q. C., and L. D. participated in experiments and conducted the experimental work. All authors read and approved the final manuscript.

\section{REFERENCES}

Acciaresi, H. A., E. A. Tambussi, M. Antonietta, M. S. Zuluaga, F. H. Andrade and J. J. Guiamét. 2014. Carbon assimilation, leaf area dynamics, and grain yield in contemporary earlier-and latersenescing maize hybrids. Eur. J. Agron. 59: 29-38.

Borrell, A., G. Hammer and E.V. Oosterom. 2001. Stay-green: A consequence of the balance between supply and demand for nitrogen during grain filling? Ann. Appl. Biol. 138(1): 91-95.

Borrell, A. K. and G. L. Hammer. 2000. Nitrogen dynamics and the physiological basis of stay-green in sorghum. Crop Sci. 40(5): 1295-1307.

Bertolino, A. V. F., N. F. Fernandes, J. P. L. Miranda, A. P. Souza, M. R. S. Lopes and F. Palmieri. 2010. Effects of plough pan development on surface hydrology and on soil physical properties in Southeastern Brazilian plateau. J. Hydrol. 393(12): 94-104.

Cai, H., W. Ma, X. Zhang, J. Ping, X. Yan, J. Liu, J. Yuan, L. Wang and J. Ren. 2014. Effect of subsoil tillage depth on nutrient accumulation, root distribution, and grain yield in spring maize. Crop J. 2(5): 297-307.

Chen, X., F. Chen, Y. Chen, Q. Gao, X. Yang, L. Yuan, F. Zhang and G. Mi. 2013. Modern maize hybrids in Northeast China exhibit increased yield potential and resource use efficiency despite adverse climate change. Glob. Chang. Biol. 19(3): 923-936.

Chen, Y., C. Xiao, X. Chen, Q. Li, J. Zhang, F. Chen, L. Yuan and G. Mi. 2014. Characterization of the plant traits contributed to high grain yield and high grain nitrogen concentration in maize. Field Crop Res. 159(6): 1-9.

Hassan, F.U., M. Ahmad, N. Ahmad and M. K. Abbasi. 2007. Effects of subsoil compaction on yield and yield attributes of wheat in the sub-humid region of Pakistan. Soil Tillage Res. 96(1-2): 361-366.

He, P. and J. Wasaki. 2005. Endogenous hormones and expression of senescence-related genes in different senescent types of maize. J. Exp. Bot. 56(414): 1117-1128.

Jiang, X., X. Liu, E. Wang, X. G. Li, R. Sun and W. Shi. 2015. Effects of tillage pan on soil water distribution in alfalfa-corn crop rotation systems using a dye tracer and geostatistical methods. Soil Tillage Res. 150: 68-77. 
Kim, S., R. C. Sicher, H. H. Bae, D. C. Gitz, J. T. Baker, D. J. Timlin and V. R. Reddy. 2006. Canopy photosynthesis, evapotranspiration, leaf nitrogen, and transcription profiles of maize in response to $\mathrm{CO}_{2}$ enrichment. Glob. Chang. Biol. 12(3): 588-600.

Kosgey, J. R., D. J. Moot, A. L. Fletcher and B. A. McKenzie. 2013. Dry matter accumulation and post-silking $\mathrm{N}$ economy of "staygreen" maize (Zea mays L.) Hybrids. Eur. J. Agron. 51: 43-52.

Li, G., F. T. Yang, X. L. Jiang, F. X. Chen, T. H. Cao and L. C. Wang. 2013. Effects of plow pan on SPAD value and chloroplast ultrastructure in leaves of spring maize. Phyton. 82: 243-247.

Li, X., L. Zhou, F. Liu, Q. Zhou, J. Cai, X. Wang, T. Dai, W. Cao and D. Jiang. 2016. Variations in protein concentration and nitrogen sources in different positions of grain in wheat. Front. Plant Sci. 7: 942.

Li, Y., X. Yang, B. Ren, Q. Shen and S. Guo. 2012. Why nitrogen use efficiency decreases under high nitrogen supply in rice (Oryza sativa L.) Seedlings. J. Plant Growth Regul. 31(1): 47-52.

Liu, X., X. Zhang, S. Chen, H. Sun and L. Shao. 2015. Subsoil compaction and irrigation regimes affect the root-shoot relation and grain yield of winter wheat. Agric. Water Manage. 154: 59-67.

Ishaq, M., M. Ibrahim, A. Hassan, M. Saeed and R. Lal. 2001. Subsoil compaction effects on crops in Punjab. Soil Tillage Res. 60: 153-161.

Martin, A., X. Belastegui-Macadam, I. Quillere, M. Floriot, M. H. Valadier, B. Pommel, B. Andrieu, I. Donnison and B. Hirel. 2005. Nitrogen management and senescence in two maize hybrids differing in the persistence of leaf greenness: Agronomic, physiological and molecular aspects. New Phytol. 167(2): 483-492.

Masclaux, D. C., M. Reisdorfcren and M. Orsel. 2008. Leaf nitrogen remobilisation for plant development and grain filling. Plant Biol. 10 Suppl 1: 23-36.

Moreno, F., E. J. Murer, E. Stenitzer, J. E. Fernández and I. F. Girón. 2003. Simulation of the impact of subsoil compaction on soil water balance and crop yield of irrigated maize on a loamy sand soil in SW Spain. Soil Tillage Res. 73(1-2):31-41.

Ning, P., S. Li, P. Yu, Y. Zhang and C. Li. 2013. Post-silking accumulation and partitioning of dry matter, nitrogen, phosphorus and potassium in maize varieties differing in leaf longevity. Field Crop Res. 144: 19-27.

Nunes-Nesi, A., A. R. Fernie and M. Stitt. 2010. Metabolic and signaling aspects underpinning the regulation of plant carbon nitrogen interactions. Mol. Plant. 3(6): 973-996.

Paponov, I. A. and C. Engels. 2003. Effect of nitrogen supply on leaf traits related to photosynthesis during grain filling in two maize genotypes with different $\mathrm{N}$ efficiency. J. Plant Nutr. Soil Sci. 166(6): 756-763.

Robson, P. R. H., I. S. Donnison, K. Wang, B. Frame, S. E. Pegg, A. Thomas and H. Thomas. 2004. Leaf senescence is delayed in maize expressing the Agrobacterium IPT gene under the control of a novel maize senescence-enhanced promoter. Plant Biotechnol. J. 2(2): 101-112.

Reicosky, D. C. and D. W. Archer. 2007. Moldboard plow tillage depth and short-term carbon dioxide release. Soil Tillage Res. 94(1): 109-121.

Széles, A. V., A. Megyes and J. Nagy. 2012. Irrigation and nitrogen effects on the leaf chlorophyll content and grain yield of maize in different crop years. Agric. Water Manage. 107(10): 133-144.

Ta, C. T. and R. T. Weiland. 1992. Nitrogen partitioning in maize during ear development. Crop Sci. 32(2): 443-451.

Thoiron, S. and J. F. Briat. 1999. Differential expression of maize sugar responsive genes in response to iron deficiency. Plant Physiol. Biochem. 37(10): 759-766.

Tollenaar, M. 1989. Genetic improvement in grain yield of commercial maize hybrids grown in Ontario from 1959 to 1988. Crop Sci. 29(6): 1365-1371.

Xu, H., Y. Lu and Z. Xie. 2016. Effects of silicon on maize photosynthesis and grain yield in black soils. Emir. J. Food Agric. 28(11): 779-785. 